\title{
Influence of zeolite suspension concentration on microfiltration characteristics
}

\author{
Tomáš Bakalár, Štefan Sabo, Milan Búgel, Branislav Loch \\ Technical University of Košice, Faculty of Mining, Ecology, Process Control and Geotechnologies; \\ e-mail:tomas.bakalar@tuke.sk
}

(C) 2015 Authors. This is an open access publication, which can be used, distributed and reproduced in any medium according to the Creative Commons CC-BY 4.0 License requiring that the original work has been properly cited.

Crossflow microfiltration is a very effective and energy efficient separation method allowing separation of very fine particles from liquids. It is mainly used for separation of particles from 0.1 to 10 microns. These membrane processes are used for separation of solids from liquids in pharmaceutical, chemical, food, and dairy industries as well as in environmental protection and water treatment (Fadaei et al. 2007, Chellam et al. 2011).

Ceramic membranes are often used for treatment of water. These membranes are preferred for their higher chemical, mechanical, and thermal resistance compared with organic membranes. Membranes form a physical barrier to the sludge, bacteria and suspended particles. Microstructural parameters as pore size, pore density, and porosity of the membrane have a great influence on the permeate flux (Ogunbiyi et al. 2008, Altunkaynak et al. 2010).

Zeolites occur in a number of variations such as clinoptilolite and chabazite. Clinoptilolite is the most abundant zeolite and is easily available in more than 40 varieties. Natural and also synthetic zeolites have unique physical, chemical and structural properties. Therefore zeolites are widely used in technological, environmental and agricultural processes. One of the most studied zeolites, clinoptilolite showed the highest selectivity for some heavy metals ions such as $\mathrm{Pb}^{2+}, \mathrm{Cd}^{2+}, \mathrm{Zn}^{2+}$ and $\mathrm{Cu}^{2+}$ (Babel et al. 2003). In the experiments natural zeolite was used from Nižný Hrabovec in the Slovak Republic. The structure is composed from three-dimensional grid, the main mineral is clinoptilolite. Clinoptilolite is composed of a tetrahedron $\left(\mathrm{SiO}_{4}\right)^{4-}$ connected by oxygen atoms, and a part of the silicon atoms is replaced with aluminum atoms. The total volume of the cavities of the zeolite is from 24 to $32 \%$. The volume density is from 1600 to $1800 \mathrm{~kg} \cdot \mathrm{m}^{-3}$, the density from 2200 to $2440 \mathrm{~kg} \cdot \mathrm{m}^{-3}$ and the specific surface is from 30 to $60 \mathrm{~m}^{2} \cdot \mathrm{g}^{-1}$ (www.zeocem.com).

For the experimental measurements special laboratory microfiltration apparatus was used. The filtered suspension was pumped using a membrane pump from a reservoir (4 liters volume) into membrane module, in which the ceramic membrane with porosity of $50 \mathrm{~nm}$ is placed. Magnetic flow meter measured the flow of the suspension. The values of the input and output transmembrane pressure were recorded from gauges. From the membrane module permeate flowed to collecting bottle. The collecting bottle was placed on a lab balance. The monitored data (pressure, suspension flow rate, permeate flow and temperature) were processed by a computer program. The temperature of the suspension was maintained at $25^{\circ} \mathrm{C}$, the pressures were in the range from 40 to $100 \mathrm{kPa}$ and the flow rate of the suspension was $2.2 \mathrm{~m} \cdot \mathrm{s}^{-1}$.

The measurements were focused on determination of the stability of the microfiltration system using different pressures and different concentrations of suspensions of zeolite. Experiments were performed to determine the permeate flux in the microfiltration of suspensions of zeolite at concentration of $3 \mathrm{~g} \cdot \mathrm{L}^{-1}, 6 \mathrm{~g} \cdot \mathrm{L}^{-1}$ and $9 \mathrm{~g} \cdot \mathrm{L}^{-1}$, at a constant pressure of $100 \mathrm{kPa}$ and a constant rate of suspension flow of $2.2 \mathrm{~m} \cdot \mathrm{s}^{-1}$. After stabilization 
of the system, and after the addition of a given concentration of zeolite to the apparatus in all three cases it is possible to see a decrease in membrane flux to a value of about $310 \mathrm{~L} \cdot \mathrm{m}^{-2} \cdot \mathrm{h}^{-1}$. However this flux has not remained constant, but in the course of the experiment continued to decrease to a final value of $280 \mathrm{~L} \cdot \mathrm{m}^{-2} \cdot \mathrm{h}^{-1}$. This decrease indicates that under these conditions there is some fouling of the membrane at relatively low concentrations of the zeolite suspension.

Due to membrane fouling experiments with gradual increasing and then decreasing of pressures were performed. In the experiments at a constant suspension flow rate of $2.2 \mathrm{~m} \cdot \mathrm{s}^{-1}$ and a constant concentration of zeolite suspension of $3 \mathrm{~g} \cdot \mathrm{L}^{-1}$ the pressure in the apparatus was gradually varied from 40 to $70 \mathrm{kPa}$ and then back to $60 \mathrm{kPa}$ and $50 \mathrm{kPa}$. For each of these pressures the system was allowed to stabilize for $30 \mathrm{~min}$. From the comparison of the levels of flow rates at $60 \mathrm{kPa}$ and $50 \mathrm{kPa}$ it may be seen that in both cases a decrease in flux occurs after reduction of pressure. Therefore, it can be concluded that in the microfiltration experiments with the membrane and zeolite used it is preferably to use lower operating pressure of $70 \mathrm{kPa}$.

In the following experiments therefore the pressure of $50 \mathrm{kPa}$ was used. These experiments were carried out at constant pressure and constant rate of $2.2 \mathrm{~m} \cdot \mathrm{s}^{-1}$. Concentrations of zeolite were varied by $1 \mathrm{~g} \cdot \mathrm{L}^{-1}$ to a final concentration of $30 \mathrm{~g} \cdot \mathrm{L}^{-1}$. The system was stable at low concentrations of zeolites and there was no initial decrease of flow. In the experiments with higher zeolite concentrations has also been shown that even at the highest concentration of used zeolite suspension of $30 \mathrm{~g} \cdot \mathrm{L}^{-1}$ there was no decrease in membrane flux. This flux was approx. $150 \mathrm{~L} \cdot \mathrm{m}^{-2} \cdot \mathrm{h}^{-1}$ and further did not decrease.

\section{REFERENCES}

Altunkaynak A. \& Chellam S., 2010. Prediction of specific permeate flux during crossflow microfiltration of polydispersed colloidal suspensions by fuzzy logic models. Desalination, 253, 188-194.

Babel S. \& Kurniawan T.A., 2003. Low-cost adsorbents for heavy metals uptake from contaminated water: a review. Journal of Hazardous Materials, B97, 219-243.

Chellam S. \& Cogan N.G., 2011. Colloidal and bacterial fouling during constant flux microfiltration: Comparison of classical blocking laws with a unified model combining pore blocking and EPS secretion. Journal of Membrane Science, 382, 148-157.

Fadaei H., Tabaei S.R. \& Roostaazad R., 2007. Comparative assessment of the efficiencies of gas sparging and backflushing to improve yeast microfiltration using tubular ceramic membranes. Desalination, 217, 93-99.

Ogunbiyi O.O., Miles N.J. \& Hilal N., 2008. The effects of performance and cleaning cycles of new tubular ceramic microfiltration membrane fouled with a model yeast suspension. Desalination, 220, 273-289. 